\title{
Notes on the map of the left periphery in Danish
}

\author{
Luigi Rizzi \\ University of Geneva \& University of Siena
}

\begin{abstract}
Vikner (1991) showed that certain complex complementizer sequences, in particular the som at der sequence in subject relatives, are possible in Danish. In this note, I argue that such sequences are naturally amenable to a cartographic analysis, in which the som particle expresses the highest structural layer in relative clauses, the at particle occupies the position in which this element normally occurs in embedded declaratives, and der occupies the Fin position in subject relatives. Such a nominal specification of Fin licenses subject movement much as $-i$ in qui French relatives according to the analysis presented in Rizzi \& Shlonsky (2007). I argue that the high "analyticity" (in (Huang's 2015 sense) of the Danish complementizer system offers interesting evidence for the general map of the left periphery.
\end{abstract}

\section{Introduction}

Vikner (1991) (henceforth V91) analyzes sentences displaying different complementizer particles cooccuring in the left periphery in certain Danish constructions. ${ }^{1}$ Two or even three complementizer particles can co-occur,

1 All the Danish examples in this paper are taken (or minimally adapted) from Vikner (1991), which was published well before the cartography of the left periphery, and in fact was among the papers suggesting that there is more in the $\mathrm{C}$ system than just a single $\mathrm{X}$-bar schema. This and other papers identifying sequences of complementizer particles in different languages encouraged me to undertake the study of the fine structure of the clausal periphery in a fully systematic way. The preparation of this text led me back to many enriching discussions Sten and I had in Geneva during his graduate studies. I hope Sten will enjoy reading these notes based on his work.

Ken Ramshøj Christensen, Henrik Jørgensen \& Johanna L. Wood (eds.). 2019.

The Sign of the V-Papers in Honour of Sten Vikner. Dept. of English, School of Communication \& Culture, Aarhus University, pp. 489-501, doi:10.7146/aul.348.112. (C) The author(s). 
giving rise to sequences such as som at der, marginally acceptable in subject relatives ${ }^{2}$ :

(1) ?Vi kender mange lingvister som at der vil læse denne bog. We know many linguists which that there will read this book 'We know many linguists who will read this book.' (V91: 112, (5))

Such complex sequences traditionally evoked some notion of "CP recursion". ${ }^{3}$ But clearly this notion must be constrained. We do not have free recursion, as only certain orders are permitted: Any permutation of the som at der order leads to ungrammaticality.

Cartographic studies of the left periphery of the clause offer a natural framework for structuring the notion of CP recursion. Current analyses of the cartography of the left periphery of clauses have put forth the hypothesis that the complementizer system is populated by a sequence of functional heads, which

1. express general properties of the clause, such as its force (or clause type) and finiteness, or

2. host various kinds of operators (relative, interrogative, exclamative, ...), or

3. create articulations for discourse-related properties such as topic-comment and focus-presupposition.

See Rizzi (1997) for the original proposal, and Rizzi \& Bocci (2017) and Rizzi \& Cinque (2016) for recent overviews.

In what follows I will try to capture some of Vikner's (1991) empirical discoveries in terms of a cartographic analysis, and sketch out a map of the Danish left periphery consistent with these findings. Let me proceed by reviewing the individual properties of the complementizer particles which can give rise to the observed sequences, and then consider the possible combinations that can arise.

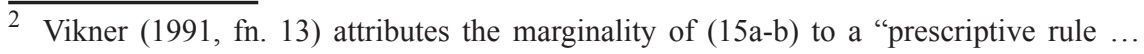
regarding the co-occurrence of som and $a t^{\prime \prime}$.

3 As in Vikner (1994) in the context of embedded V2 phenomena. See also Nyvad, Christensen \& Vikner (2017) and Vikner, Christensen \& Nyvad (2017) for a left-peripheral map based on the $\mathrm{c} / \mathrm{C}$ distinction, which I will not discuss here. 


\section{Der}

Der is the complementizer particle which occurs in subject relatives and embedded subject questions:

(2) Vi kender de lingvister (som) der vil læse denne bog. We know the linguists will read this book

'We know the linguists who will read this book.' (V91: 115, (14a-b))

(3) $\mathrm{Vi}$ ved ikke hvilke lingvister der vil læse denne bog. We know not which linguists there will read this book

'We don't know which linguists who will read this book.'

(V91: 115, (14c))

In Vikner's analysis (building on Taraldsen 1986) this instance of der, homophonous with existential expletive der (akin to English there) is a manifestation of the $\mathrm{C}$-system licensing a subject trace. Vikner establishes a parallel with the que>qui rule in French and the $d a>$ die rule in West Flemish (Bennis \& Haegeman 1983), and interprets the role of this element as a proper governor for the subject trace in terms of the ECP-based account proposed in Rizzi (1990). Much as qui and die, der also licenses extraction from an embedded declarative, alleviating a that-trace (or, in Danish, attrace) effect:

a. *Jeg ved ikke hvem du tror at _ vil læse I know not who you believe that _ will read denne bog. this book

b. Jeg ved ikke hvem du tror at der vil læse I know not who you believe that there will read denne bog. this book

Der is homophonous with expletive der, occurring in subject position in existential sentences. Could it be that der in (4b) also occurs in subject position, much as expletive der, thus eliminating the offending trace? More precisely, one could make the hypothesis that, if der occurred in subject position, satisfying classical EPP (expressing the obligatoriness of subject positions in clauses, as in Chomsky 1981), extraction of the subject 
from a lower position would be permitted. Under these assumptions, the analysis of the alleviating effect in (4b) would be fully parallel to the approach proposed in Rizzi $(1982,1990)$ to account for the lack of that trace effects in Null Subject Languages, except that in Danish (a non-Null Subject language) the expletive would be overt, rather than pro. ${ }^{4}$

But things are more complicated. Vikner argues that the occurrence of $d e r$ is (4b) is in fact the realization of a head in the complementizer zone, rather than a DP occurring in subject position. A straightforward piece of evidence for the head analysis comes from the fact that it appears in embedded questions, but not in main questions. Compare (3) and the following:

(5) Hvilke lingvister (*der) vil læse denne bog? Which linguists there will read this book 'Which linguists will read this book?'

Danish being a V2 language, the inflected verb (the auxiliary in (5)) must move head to head to the C-system, hence V2 is inconsistent with an overtly realized C-particle (this follows from virtually all approaches to V2 involving movement of the inflected V to the C-system, from Den Besten 1977/83 to Vikner 1990, 1995 to the recent cartographic approach in Samo 2018). Der can occur in embedded questions like (3) because V2 does not apply in such embedded environments. So, the asymmetry (3)-(5) follows from the root character of $\mathrm{V} 2$, but this requires analyzing der as a $\mathrm{C}$-head, rather than as a DP.

\section{Recasting ECP effects in terms of Criterial Freezing}

Another issue that requires discussion is the reliance on the ECP of classical analyses of that - trace effects. The ECP of GB theory does not have a natural place in the principled typology of principles introduced by the Minimalist Program, and is inconsistent with Minimalism for other more technical reasons, such as the reliance on government.

In the last decade or so, the classical ECP approach to that-trace effects has been recast in terms of criterial freezing through the following ingredients (on which see Rizzi 2006, Rizzi \& Shlonsky 2007, Rizzi 2016 among many other references):

4 Of course, independent differences would remain, such as non-availability in Danish of the low focus position utilized for subject focalization in Italian (Belletti 2009). 
(5) a. Criterial freezing: a phrase meeting a Criterion is frozen in place, and becomes unavailable to further movement. ${ }^{5}$

b. There is a Subject Criterion, triggered by the Subj head, an obligatory component of the clausal spine.

The obligatoriness of the subject position, the extended clause of the Projection Principle (EPP) of the GB framework, is expressed in this way, and is akin to the obligatoriness of other heads of the IP system, such as T.

So, for instance, the derivation of (4a) would go through a derivational stage in which the wh-element hvem is attracted to the Spec of Subj:

$$
\begin{aligned}
& \text { a. ....at hvem Subj vil læse denne bog. } \\
& \text {...that who }
\end{aligned}
$$

At this point hvem satisfies the Subject Criterion, hence it is not further movable to a higher position under Criterial Freezing. This captures the $a t$-trace effect.

Languages use different kinds of devices to overcome the freezing effect and make subject movement possible (Rizzi \& Shlonsky 2007). According to this reference, French $q u i$, or rather $-i$, fusing with the regular force marker que and yielding $q u-i$, is a special nominal realization of the lowest head of the CP system, Fin(iteness). Such an element can be merged directly with Subj, thus formally satisfying the Subject Criterion, and allowing the thematic subject to be extracted from a lower position, without having to pass through the freezing position (which would make the continuation of movement impossible; see Rizzi \& Shlonsky 2007 for a more precise characterization, and Berthelot 2017 for various refinements and developments of this analysis):

(6) French

Qui crois-tu qu-i $\mathrm{i}_{+\mathrm{N}}$ Subj viendra _?

Who think-you qu-i will.come

'Who do you think will come?'

So, the nominal finiteness head formally satisfies the Subj criterion: It is not in a Spec-head configuration with Subj, rather it is in a head-head configuration; but the two configurations are formally close enough to

5 The freezing effect may in turn be derived from the labeling algorithm and a maximality principle, along the lines proposed in Rizzi (2016). 
unify them, as far as criterial satisfaction is concerned (both configurations involve strictly local c-command, c-command without any intervening material, which can be considered the configuration involved in criterial satisfaction).

In conclusion, der may be seen as a nominal realization of Fin, locally satisfying the Subject Criterion and permitting subject movement, e.g. in (4b), which will have the following representation ${ }^{6}$ :

$$
\begin{aligned}
& \text { b. Jeg ved ikke hvem du tror } \\
& \text { I know not who you believe } \\
& {\left[_ { \text { Forcep } } \text { at } \left[_ { \text { FinP } } \operatorname { d e r } _ { + \mathrm { N } } \left[_{\text {Subj P }}\right.\right.\right. \text { Subj vil læse denne bog. }} \\
& \text { that COMP will read this book } \\
& \text { 'I don't know who you belive will read this book.' }
\end{aligned}
$$

From the viewpoint of this analysis, the at der sequence shown in (4'b) is akin to French $q u-i$, except that the two complementizer elements are not morphologically fused together in Danish, and more transparently express force (at) and finiteness (der).

Analyzing $d e r$ as a particular realization of the Fin head immediately captures its incompatibility with $\mathrm{V} 2$ because $d e r$ occupies a head position which the inflected verb must move to in V2; this analysis also captures the other pieces of evidence presented in Vikner (1991) for distinguishing der in (1), (4b), etc., from existential der, occupying the subject position (consistent with V2, requiring the indefiniteness of the associate, limited to occur with certain verb classes, whereas der qua nominal marker of finiteness has none of these properties).

As for the position of der in the map of the left periphery, if the role of der in (1), (4b), etc. is to permit subject movement by formally satisfying the Subject Criterion, it is expected that der should appear in the lowest position of the CP system, close enough to Subj to satisfy the Subject Criterion. That is why der closes the complementizer sequence downward in (1), and cannot occur in any other position.

The possible occurrence of (this instance of) der is strictly limited to

\footnotetext{
6 As for main questions (Hvem lceste bogen? "Who read the book?"), various options are considered in Rizzi \& Shlonsky (2007) for similar cases in other languages. One possibility is that the inflected verb, moving to the C-system, takes along the Subj head, thus creating via head-movement a complex head including both Q and Subj, so that both the Subject Criterion and the Q Criterion are fulfilled simultaneously by Hvem in its left peripheral landing site.
} 
the cases in which the moved element is the subject. In all other cases, e.g., of object relatives or questions, der cannot appear, neither alone nor preceded by other $\mathrm{C}$ particles:

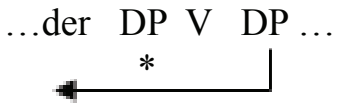

Why does this constraint hold? Vikner adopts and extends to these cases the agreement approach of Rizzi (1990). In terms of the approach I am adopting here, one could adapt that analysis as follows: The $+\mathrm{N}$ feature of der must be checked by a nominal expression in its Spec, and der attracts the closest expression endowed with $+\mathrm{N}$, the subject. So, the derivational step indicated by the arrow in (7) can never occur because of locality. Therefore, der is limited to occur in cases of local subject extraction.

\section{At}

In examples like (4)b, at clearly occupies the highest position of the complementizer space, expressing declarative Force. At is unable to formally satisfy the Subject Criterion, whence the at-trace effect, much as English that, French que:

\section{(8) Danish}

*Jeg ved ikke hvem du tror at _ vil læse denne bog. I know not who you believe that _ will read this book

\section{(9) English}

*Who do you believe that _ will read this book?

\section{(10) French}

*Qui crois-tu que _ lira ce livre?

Who believe-you that will.read this book?

'Who do you believe will read this book.'

The element corresponding to that does not have this property in all languages. (I am putting aside here null subject languages, which systematically lack that-trace type effects: Rizzi 1982, 1990): Norwegian permits the equivalent of (8), much as certain varieties of English (Sobin 2002), so that some parametrization must be assumed, a topic which I 
will not address in this paper (see Rizzi \& Shlonsky 2007 for an approach consistent with the current assumptions).

Elements like English that and Romance que manifest a considerable versatility, appearing in distinct positions of the complementizer space (sometimes with the possibility that two instances may co-occur in distinct positions: Villa-Garcia 2012, Radford 2013). Nevertheless, the unmarked hypothesis, to be adopted in the absence of evidence to the contrary, is that when an element appears in different constructions in the same language, it occupies the same position. I will follow this logic and assume that at occurring after som in relative clauses like (1) occupies the same position it occupies in embedded declaratives like (4b), hence the position of declarative Force.

\section{Som}

Som is a complementizer head specialized for relative clauses. It cannot cooccur with a relative with an overt $w h$-operator, as in the genitive relative (11a), but it is allowed in object and subject relatives, in which no overt $w h$ operator occurs, as in (11b-c):

$\begin{array}{llllll}\text { (11) a. Jeg kender en pige hvis hund (*som) } & \text { spiser } & \text { æbler. } \\ I & \text { know a girl whose dog } & \text { eats apples }\end{array}$ 'I know a girl whose dog eats apples.' (V91: 111, (2))

b. Jeg kender en bog som denne lingvist har skrevet. I know a book which this linguist has written 'I know a book which this linguist has written.' (V91: 111, (4d))

c. Vi kender de lingvister som vil læse denne bog. We know the linguists who will read this book 'We know the linguists who will read this book.'

(V91: 125, (43d))

Following Vikner (1991), I will assume that som is the relative complementizer co-occurring with a null relative operator, i.e., when the Relative Criterion is satisfied by a null operator in its Spec. ${ }^{7}$ The distribution is thus similar to English relative that, or Italian relative che, except that a dedicated form appears in Danish, distinct from the declarative complementizer.

7 If a raising analysis is adopted, some other assumption should be made, which I will not try to develop here. For concreteness, I will continue to adopt the null operator analysis in this paper. 
That relatives may be introduced by dedicated heads is not at all an unusual situation. What is special in Danish is that such a dedicated complementizer cooccurs with, and precedes, the unmarked declarative complementizer at. This provides important evidence on the shape of the CP system of relative clauses.

In Rizzi (1997) it was observed that the CP layer hosting relative pronouns is the highest layer of the system, in that it can (and must) precede topic(s) and focus, as in (12a); the same ordering properties hold for subject or object relatives, which plausibly involve a null operator and the overt declarative complementizer che, as in (12b):

\section{(12) Italian}

a. Questa è la persona a cui, la commissione, quest' anno, This is the person to whom the committee, this year,

IL PRIMO PREMIO dovrebbe dare.

THE FIRST PRIZE should give

'This is the person to whom this year the committee should give THE FIRST PRIZE.'

b. Questa è la commissione che a Gianni, quest' anno, This is the committee that to Gianni, this year, ANCHE IL PRIMO PREMIO gli potrebbe dare. EVEN THE FIRST PRIZE could give This is the committee that, this year, could give EVEN THE FIRST PRIZE to Gianni.'

It was then assumed that the criterial position defining relatives, hence the locus of the relative criterion, corresponded to the highest position postulated for the CP system, the Force layer in that system. This assumption is non-optimal though: In particular, it appears to conflict with the "one property, one feature, one head" guideline, which in principle rules out heads endowed with more than a single categorial feature (see Rizzi 2017 for some necessary qualifications of the guideline, which nevertheless leave its heuristic force intact).

Such examples as (1), and the fact that the dedicated relative complementizer som precedes at, now suggest a different map, one in which the Rel head and its projection precedes and is higher than the (declarative) force head, expressed by at: 
(13) ?Vi kender mange lingvister

We know many linguists

$\left[_{\text {RelP }}\right.$ Op som $\left[_{\text {Forcep }}\right.$ at $\left[_{\text {FinP }}\right.$ der vil læse denne bog $\left.\left.]\right]\right]$. which that there will read this book

'We know many linguists who will read this book.'

Representation (13) now complies with the guideline. If we look at it under cartographic lenses, the highly analytical structure of the Danish complementizer system, far from being a quirk of a particular language, may reveal deep properties of the general structure of the left periphery. What remains "special" about the Danish C (compared, e.g., to the English C) is that distinct overt particles can co-occur. Nevertheless, this is far from unusual in comparative terms: see, e.g., the discussion of the point in Rizzi (2013: sec. 6). Under a cartographic perspective, rich functional sequences are the general case, a major element of superficial variation being located in the spell-out properties of the distinct heads, a low-level parametric property.

\section{Conclusion: the Danish $C$ sequence}

According to Vikner (1991) analysis, Danish admits the following sequences of overt C-elements:
a. som at der
b. som at
c. som der
d. at der

The permissible sequences are illustrated by the following examples ${ }^{8}$ :

(15) a. ?Vi kender mange lingvister som at der vil læse denne bog. We know many linguists will read this book 'We know many linguists who will read this book.' (V91: 112, (5))

b. ?Vi kender en bog som at denne lingvist vil læse. We know a book this linguist will read 'We know a book that this linguist will read.'

\footnotetext{
8 Again, with the slight marginality of (15a-b) possibly due to the violation of a prescriptive rule. See fn. 2 .
} 
c. Vi kender de lingvister som der vil læse denne bog. We know the linguists will read this book 'We know the linguists who will read this book.'

(V91: 115, (14b))

d. Jeg ved ikke hvem du tror at der vil læse denne bog. I know not who you believe will read this book 'I don't know who you believe will read this book.'

(V91: 134, (64c))

This supports a partial map like the following:

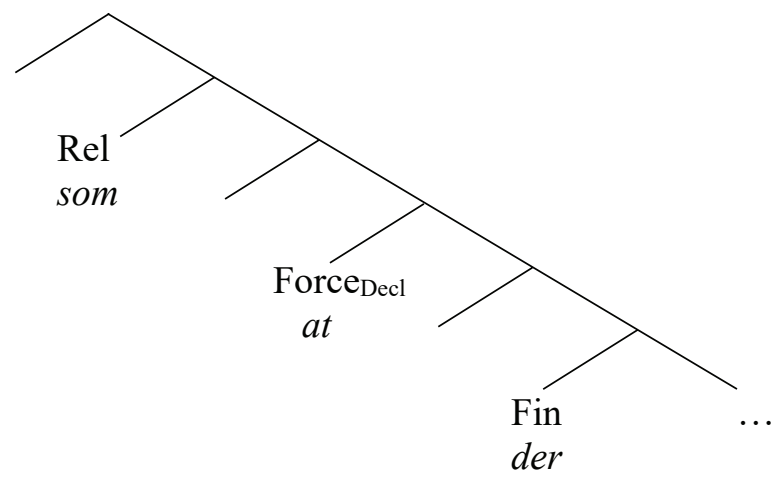

Som necessarily opens the sequence, as it must be adjacent to the relative head; der necessarily closes the sequence, as it must be adjacent to the first layer of the IP space, the SubjP, in order to make subject extraction possible in spite of Criterial Freezing. ${ }^{9}$ At thus occurs in the middle. A declarative Force marker normally occurs in the highest position in an embedded clause (e.g. in (15d)), so that the information that it encodes is immediately accessible to the higher selector. But in a relative clause it may be embedded under an even higher layer hosting the relative operator and expressing the Relative Criterion. The high "analyticity" (in Huang 2015's sense) of the Danish C-system offers interesting evidence for this conclusion, which is also in line with a fundamental cartographic guideline.

9 Ken Ramshøj Christensen (p.c.) raises the question of what structural representation can be assigned to subject relatives simply introduced by $\operatorname{der}$ (one option in (2)). I cannot fully address the point here, but let me simply say that the case is reminiscent of French subject qui relatives, which Berthelot (2017) analyzes as involving a "reduced" CP system, an option to be explored for the case at issue. 


\section{Acknowledgment}

I would like to thank Ken Ramshøj Christensen for very useful comments on an earlier draft. This research was supported in part by the ERC Grant n. 340297 "SynCart".

\section{References}

Belletti, Adriana. 2010. Structures and strategies. New York: Routledge. doi:10.4324/9780203887134.

Bennis, Hans \& Liliane Haegeman. 1984. On the status of agreement and relative clauses in West Flemish. In Wim de Geest \& Yvan Putseys (eds.), Sentential complementation, 33-55. Dordrecht: Foris.

Berthelot, Frédérique. 2017. Movement of and out of subjects in French. Geneva: University of Geneva $\mathrm{PhD}$ dissertation.

den Besten, Hans. 1977/1983. On the interaction of root transformations and lexical deletive rules. In Werner Abraham (ed.), On the formal syntax of Westgermania, 47-131. Amsterdam: Benjamins.

Chomsky, Noam. 1981. Lectures on government and binding. Dordrecht: Foris.

Huang, C.T. James. 2015. Syntactic analyticity and parametric theory. In Audrey Li, Andrew Simpson \& Wei-Tien Dylan Tsai (eds.), Chinese syntax in a crosslinguistic perspective. Oxford: Oxford University Press. doi:10.1093/acprof:o so/9780199945658.003.0001.

Nyvad, Anne Mette, Ken Ramshøj Christensen \& Sten Vikner. 2017. CP-recursion in Danish: A cP/CP-analysis. The Linguistic Review 34(3). 449-477. doi:10.1515/tlr-2017-0008.

Radford, Andrew. 2013. The complementiser system in spoken English. In Victoria Camacho-Taboada, Ángel L. Jiménez-Fernández, Javier Martín-González \& Mariano Reyes-Tejedor (eds.), Information structure and agreement, 11-54. Amsterdam: John Benjamins.

Rizzi, Luigi. 1982. Issues in Italian syntax. Dordrecht: Foris Publications.

Rizzi, Luigi. 1990. Relativized minimality (Linguistic Inquiry Monographs 16). Cambridge, MA: MIT Press.

Rizzi, Luigi. 1997. The fine structure of the left periphery. In Liliane Haegeman (ed.), Elements of grammar: Handbook in generative syntax, 281-337. Dordrecht: Kluwer Academic Publishers. doi:10.1007/978-94-011-5420-8_7.

Rizzi, Luigi. 2013. Notes on cartography and further explanation. Probus 25(1). 197-226.

Rizzi, Luigi. 2015. Labeling, maximality and the head-phrase distinction. The Linguistic Review 33(1). 103-127. doi:10.1515/tlr-2015-0016.

Rizzi, Luigi. 2017. On the format and locus of parameters: The role of morphosyntactic features. The Linguistic Review 41. 159-192. 
Rizzi, Luigi \& Guglielmo Cinque. 2016. Functional categories and syntactic theory. Annual Review of Linguistics 2(1). 139-163. doi:10.1146/annurev-linguistics-011415-040827.

Rizzi, Luigi \& Giuliano Bocci. 2017. Left periphery of the clause: Primarily illustrated for Italian. In Martin Everaert \& Henk C. van Riemsdijk (eds.), The Wiley Blackwell companion to syntax, 1-30. 2nd edn. Hoboken, NJ, USA: John Wiley \& Sons, Inc. doi:10.1002/9781118358733.wbsyncom104.

Rizzi, Luigi \& Ur Shlonsky. 2007. Strategies of subject extraction. In Hans Martin Gärtner \& Uli Sauerland (eds.), Interfaces + recursion = language? Chomsky's minimalism and the view from syntax-semantics, 115-160. Berlin: Mouton de Gruyter.

Samo, Giuseppe. 2018. A criterial approach to the cartography of v2. Geneva: University of Geneva $\mathrm{PhD}$ dissertation.

Sobin, Nicholas. 2002. The Comp-trace effect, the adverb effect and minimal CP. Journal of Linguistics 38(3). 527-560. doi:10.1017/S0022226702001652.

Taraldsen, Knut Tarald. 1986. Som and the binding theory. In Lars Hellan \& Kirsti Koch Christensen (eds.), Topics in Scandinavian syntax, 149-184. Dordrecht: Springer Netherlands. doi:10.1007/978-94-009-4572-2_8.

Vikner, Sten. 1990. Verb Movement and the licensing of NP-positions in the Germanic languages. Geneva: University of Geneva $\mathrm{PhD}$ dissertation.

Vikner, Sten. 1991. Relative der and other $\mathrm{C}^{\circ}$ elements in Danish. Lingua 84(2-3). 109-136. doi:10.1016/0024-3841(91)90067-F.

Vikner, Sten. 1995. Verb movement and expletive subjects in the Germanic languages. Oxford: Oxford University Press.

Vikner, Sten, Ken Ramshøj Christensen \& Anne Mette Nyvad. 2017. V2 and cP/ CP. In Laura Bailey \& Michelle Sheehan (eds.), Order and structure in syntax I: Word order and syntactic structure (Open Generative Syntax 1), 313-324. Berlin: Language Science Press. doi:10.5281/zenodo.1117724.

Villa-García, Julio. 2012. Recomplementation and locality of movement in Spanish. Probus 24. 257-314.

Villa-Garcia Villa-García, Julio. 2015. The syntax of multiple que sentences in Spanish. Along the left periphery. Amsterdam: John Benjamins. 